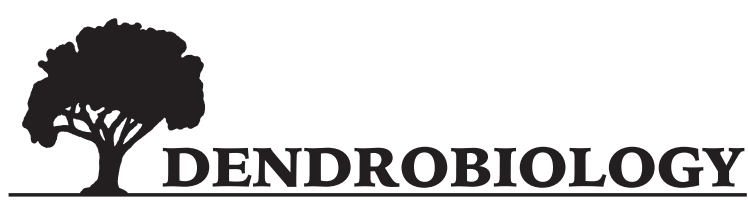

2018, vol. 79, 119-130

http://dx.doi.org/10.12657/denbio.079.011

\author{
Bulat Zubairov, Karl-Uwe Heußner, Hilmar Schröder
}

\section{Searching for the best correlation between climate and tree rings in the Trans-Ili Alatau, Kazakhstan}

\author{
Received: 11 October 2017; Accepted: 1 March 2018
}

\begin{abstract}
The result of correlation analysis between tree-ring growth and climate is the key indicator in dendroclimatic investigations. Combinations of different climate datasets with different tree-ring parameters of Schrenk spruce (Picea schrenkiana Fisch. et Mey.), give different correlation results.

Samples for this study were collected in spruce forests of northern Tian Shan in the southeastern part of Kazakhstan. Several combinations of monthly, daily, gridded and station climate data with earlywood (EW), latewood (LW), total ring width (TRW) of young, old and mixed (old and young) trees were checked. EW showed the best correlations with precipitation, LW with temperature and TRW with Standardized Precipitation-Evapotranspiration Index (SPEI). Correlation analysis indicates that daily climate data in combination with EW and LW provide best results. Strongest correlation with precipitation was found for EW of old trees, for the period July $6^{\text {th }}-$ November $3^{\text {rd }}$ (previous year), $r=0.64(p<0.05)$. LW of agemixed trees showed correlation with temperature of current year. Strongest correlations: with average temperature, for the period June $11^{\text {th }}-$ August $4^{\text {th }}, \mathrm{r}=-0.67$; with maximum temperature, for the period June $25^{\text {th }}-$ July $17^{\text {th }}, \mathrm{r}=-0.66(\mathrm{p}<0.05)$ and with minimum temperature for the period June $11^{\text {th }}-$ August $4^{\text {th }}, r=-0.64(p<0.05)$. TRW of young trees showed the strongest correlation with the Standardized Precipitation-Evapotranspiration Index 12, for June of current year, $r=0.61(p<0.05)$. Finally a shifting of strongest correlation between EW of mixed trees and precipitation was found. The strongest correlations with gridded data were found in previous July and with station data in previous October.

This study provides new information for understanding the relationships between tree-ring growth and climate in the Trans-Ili Alatau.
\end{abstract}

Keywords: Dendrochronology, Tian Shan, Schrenk spruce, Picea schrenkiana Fisch. et Mey, dendroclimatology

Addresses: B. Zubairov, Humboldt-Universität zu Berlin, Faculty of Mathematics and Natural Sciences, Department of Geography, Berlin, Germany, e-mail: zubairob@geo.hu-berlin.de K.-U. Heußner, Deutsches Archäologisches Institut, Scientific Department of the Head Office, Berlin, Germany, e-mail: karl-uwe.heussner@dainst.de H. Schröder, Humboldt-Universität zu Berlin, Faculty of Mathematics and Natural Sciences, Department of Geography, Berlin, Germany, e-mail: hilmar.schroeder@geo.hu-berlin.de 


\section{Introduction}

The main goal of dendroclimatic investigations is the reconstruction of different climatic parameters. In order to do this reconstruction, we need to understand which climatic signal we have in our tree rings. For this purpose we use correlation analysis, but the results of this analysis always depends on many parameters: sampling site, preparation of the samples, standardization process and climate dataset which are used, all these influence the final results (Schweingruber, 1996). In order to start a new research at a new place, we always have to check what kind of information is stored in our samples. The dendroclimatic investigations in Kazakhstan started in Soviet times and were especially intensive in the southeastern part of Kazakhstan in Tian Shan Mountains, where forests are dominated by Schrenk spruce (Picea schrenkiana Fisch. et Mey.). The first thorough dendroclimatic research in Kazakhstan using Schrenk spruce was conducted by Borscheva NM from the 1970s to the 1990s. She found that sensitivity of Schrenk spruce grows from West to East, from the Trans-Ili Alatau Range to the Kungey and the Terskey Alatau Ranges, which is connected with a decrease of precipitation in this direction (Borscheva, 1983). In the mountains, variations of temperature and precipitation regime are also highly influenced by altitudinal zonation (elevation and topography). In literature usually spruce forests in Tian Shan are divided in three belts: lower - from lower tree limit to $2100-2200 \mathrm{~m}$ a.s.l., middle - from $2100-2200$ to $2400-2500 \mathrm{~m}$ a.s.l. and upper - from $2400-2500$ $\mathrm{m}$ a.s.l. to upper tree limit, this division is based on differences in climatic conditions (Roldugin, 1970; Kolov et al., 2003). In northern Tian Shan the coefficients of sensitivity for earlywood (EW), latewood (LW) and total ring width (TRW), vary from 0.15 to 0.27 (Borscheva, 1983). According to Borscheva, in general old trees have higher LW content, and show higher sensitivity compared to young trees (Borscheva, 1983). Correlation analysis showed that increment of EW is influenced by cold-period weather at both upper and lower tree-limits. For the LW formation the dominant factors are precipitation from June-July to August-September of the current year and temperature from the second half of the summer to beginning of the autumn (Borscheva, 1983). Borscheva showed that growth is influenced by precipitation and temperature, but the dominant factor is autumn-winter precipitations of previous year and current year's spring precipitation. She found that the influence of humidification and thermal conditions of the previous vegetation year affects only the annual variability through the formation of vegetative buds and needles (Borscheva, 1981a; Borscheva,

Table 1. Dendroclimatic studies in the Trans-Ili Alatau based on Schrenk spruce

\begin{tabular}{|c|c|c|c|c|c|c|c|}
\hline Reference & $\begin{array}{l}\text { Tree- } \\
\text { ring } \\
\text { proxy } \\
\text { type } \\
\end{array}$ & $\begin{array}{l}\text { Forest } \\
\text { belt }\end{array}$ & $\begin{array}{l}\text { Detrending } \\
\text { Method }\end{array}$ & $\begin{array}{l}\text { Climate } \\
\text { data used }\end{array}$ & $\begin{array}{l}\text { Meteorologi- } \\
\text { cal station }\end{array}$ & Climatic signal & $\begin{array}{c}\text { Climate-growth corre- } \\
\text { lation }\end{array}$ \\
\hline $\begin{array}{l}\text { Borscheva } \\
\text { (1983) }\end{array}$ & LW & Lower & $\mathrm{n} / \mathrm{a}$ & $\begin{array}{l}\text { Monthly } \\
\text { station } \\
\text { data }\end{array}$ & $\mathrm{n} / \mathrm{a}$ & $\begin{array}{l}\text { July-August precipi- } \\
\text { tation }\end{array}$ & $\begin{array}{l}\text { With } 5 \text { years averaging, } \\
\text { from } r=0.38 \pm 0.18 \text { to } \\
0.70 \pm 0.22(p<n / a)\end{array}$ \\
\hline $\begin{array}{l}\text { Passmore et al. } \\
(2004)\end{array}$ & TRW & Middle & $\mathrm{n} / \mathrm{a}$ & $\begin{array}{l}\text { Monthly } \\
\text { station } \\
\text { data }\end{array}$ & $\begin{array}{l}\text { Bolshaya Al- } \\
\text { matinka Lake, } \\
\text { Mynzhilki and } \\
\text { Ust Gorelnik }\end{array}$ & Annual temperature & $\mathrm{r}=0.44(\mathrm{p}<\mathrm{n} / \mathrm{a})$ \\
\hline $\begin{array}{l}\text { Panyushkina et } \\
\text { al. (2010) }\end{array}$ & TRW & Upper & $\begin{array}{l}\text { Hugershoff } \\
\text { growth curve }\end{array}$ & $\begin{array}{l}\text { Monthly } \\
\text { and daily } \\
\text { station } \\
\text { data }\end{array}$ & Narin & $\begin{array}{l}\text { April } 6^{\text {th }}-\text { April } 30^{\text {th }} \\
\text { mean temperature }\end{array}$ & $r=-0.61(p<0.0001)$ \\
\hline $\begin{array}{l}\text { Chen et al. } \\
\text { (2017) }\end{array}$ & TRW & Lower & $\begin{array}{l}\text { Cubic smoothing } \\
\text { spline, with } 50 \% \\
\text { frequency-re- } \\
\text { sponse at } 70 \text { years }\end{array}$ & $\begin{array}{l}\text { Monthly } \\
\text { station } \\
\text { and grid- } \\
\text { ded data }\end{array}$ & Almaty & $\begin{array}{l}\text { SPEI }^{\text {a }} \text { (Vicente-Serrano } \\
\text { et al. 2010) (previ- } \\
\text { ous August - current } \\
\text { January) }\end{array}$ & $r=0.647(p<0.001)$ \\
\hline $\begin{array}{l}\text { Zhang et al. } \\
\text { (2017) }\end{array}$ & TRW & Lower & $\begin{array}{l}100 \text { yr - spline } \\
\text { curve }\end{array}$ & $\begin{array}{l}\text { Monthly } \\
\text { station } \\
\text { and grid- } \\
\text { ded data }\end{array}$ & Almaty & $\begin{array}{l}\text { previous June - current } \\
\text { May precipitation }\end{array}$ & $\mathrm{r}=0.63(\mathrm{p}<0.0001)$ \\
\hline $\begin{array}{l}\text { Panyushkina et } \\
\text { al. (2018) }\end{array}$ & TRW & $\begin{array}{l}\text { All } \\
\text { forest } \\
\text { belts }\end{array}$ & $\begin{array}{l}\text { Cubic smooth- } \\
\text { ing spline, with } \\
50 \% \text { frequen- } \\
\text { cy-response at a } \\
\text { wavelength of } 2 / 3 \\
\text { the sample series } \\
\text { length }\end{array}$ & $\begin{array}{l}\text { Monthly } \\
\text { station } \\
\text { and grid- } \\
\text { ded data }\end{array}$ & Almaty & $\begin{array}{l}\text { previous fall - current } \\
\text { January - February } \\
\text { precipitation } \\
\text { July - September pre- } \\
\text { cipitation } \\
\text { May - September } \\
\text { precipitation and tem- } \\
\text { perature }\end{array}$ & $\begin{array}{l}r \approx \text { from }-0.4 \text { to }-0.6 \\
(\alpha=0.01) \\
r \approx \text { from } 0.35 \text { to } 0.4 \\
(\alpha=0.01-0.05) \\
r \approx 0.3(\alpha=0.05) \\
\text { Significance estimated } \\
\text { by Monte Carlo method } \\
\text { (Meko et al. } 2011)\end{array}$ \\
\hline
\end{tabular}

${ }^{a} S P E I$ the Standardized Precipitation-Evapotranspiration Index. 
1981b; Borscheva, 1981c; Borscheva, 1981d; Borscheva, 1983; Borscheva, 1986). Other researchers have also noted the importance of the previous year precipitation, which is explained by enhanced soil moisture availability (Gan, 1970; Chen et al., 2017; Zhang et al., 2017; Panyushkina et al., 2018). We found only 5 published dendroclimatic studies conducted in the Trans-Ili Alatau since the 1990s (Table 1 ), and in general all published results are in agreement with Borscheva's. But we can obviously see the difference in input data, some researchers collected samples at upper, and others at lower tree limits. Some of them used only weather station data and others also used gridded datasets. One group investigated correlations with yearly, a second with monthly and a third with daily climate data (Passmore et al., 2004; Panyushkina et al., 2010; Zhang et al., 2017; Panyushkina et al., 2018). Borscheva investigated signals from EW and LW, whereas, other researchers used only TRW. Taking this into consideration, we set a goal to investigate how different combinations of input data affect correlation results. Also, this will be the first correlation analysis between EW, LW and daily climate data in the Trans-Ili Alatau, we hypothesize that this combination can provide the strongest correlations and more precise seasonality window of climatic signal in the tree rings variation.

\section{Data and methods}

\section{Sampling site and chronologies development}

Schrenk spruce, (Picea schrenkiana Fisch. et Mey) samples were collected in the lower tree limit (1970 $\mathrm{m}$ above sea level) of the Trans-Ili Alatau Range, Kazakhstan $\left(43.05^{\circ} \mathrm{N}, 76.45^{\circ} \mathrm{E}\right)$ near the Aksay gorge, in September 2016 (Fig. 1). Sampling was conducted on a north-facing slope (inclined at $20-25^{\circ}$ ) with a shallow soil layer following standard dendrochronological procedures outlined in Speer (2010). At least 2 cores from a total of 21 trees were sampled from individuals without signs of injury or diseases, with 38 cores suitable for further analysis.

Cores were dried, mounted and polished with progressively finer sandpapers. Prepared samples were scanned at $1200 \mathrm{dpi}$ and measured in WinDENDRO (Regent Instruments Canada Inc., 2009). The WinDENDRO is a semi-automatic system. The rings are detected based on light intensity differences and then checked visually on presence of false/ missed rings or misclassifications. Measurements for EW, LW, and TRW were divided in groups based upon tree age and includes, i) old trees (12 cores from 7 trees with a mean segment length of $\sim 150$ years), ii) young trees (12 cores from 7 trees with a mean segment length of $\sim 77$ years), and iii) mixed old and young trees (38 cores from 21 trees with a mean segment length of $\sim 103$ years). All series were visually cross-dated in the TSAPWin program (Time Series Analysis and Presentation for Dendrochronology and Related Applications; version 4.67c (C) 2002-2011 Rinntech), checked using the COFECHA program (Version 6.06P (c) 1997-2004 Absoft Corporation) and corrected if it was necessary (Holmes, 1983). Then the ARSTAN program (AutoRegressive STANdardization; MRWE Application Framework (C) 1997-2004 Absoft Corporation) was used for standardization and final data preparation for further correlation analysis (Cook \& Holmes, 1986). Datasets consisting of young trees were detrended by applying negative exponential curves, and others were detrended using the smoothing spline (step length 100). Young and old trees might have such different trends on different time scales
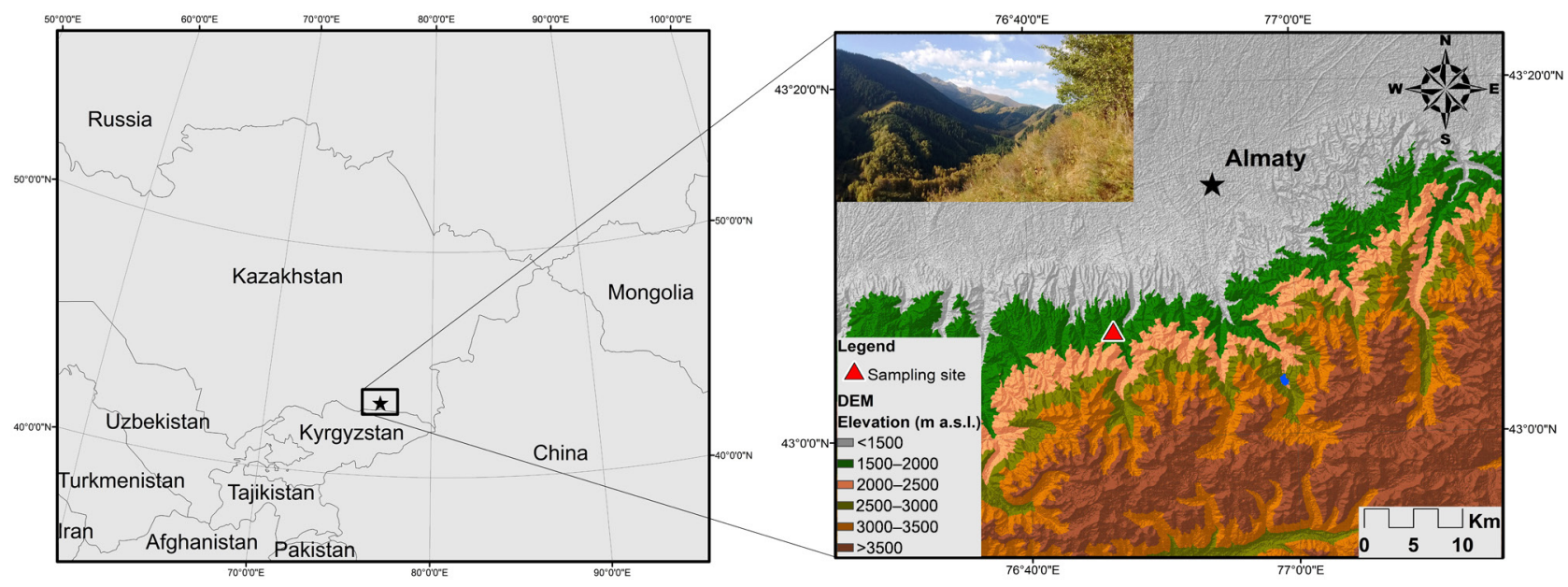

Fig. 1. Study region and photo from the site. The Digital Elevation Model (DEM) was obtained using the Advanced Spaceborne Thermal Emission and Reflection Radiometer (ASTER) Global Digital Elevation Model (GDEM) version 2 image (Tachikawa et al. 2011). The map is generated by ArcGIS 10.3 (https://www.arcgis.com/) 
that different detrending methods were necessary in order to minimize the individual non-climatic signals (noise) and maximize the common climate signal in the young and old trees. The mean interseries correlations (Rbar), the expressed population signal (EPS) and other statistics were used in order to check the quality of our chronologies. For the statistics analysis the dendrochronology program library (dplR) was applied (Bunn, 2008). The EPS of 0.85 has been chosen as an appropriate criterion to ensure the reliability of our chronologies (Wigley et al., 1984). In order to maximize the high frequency signal the residual chronologies were chosen for correlation analysis, removing autocorrelation from the series using autoregressive modeling. Finally, adaptive power transformation was used to stabilize the variance (Cook \& Peters, 1997). This was done in order to remove non-climatic variability, for example age-related growth trends and to reduce the noise caused by individual trees.

\section{Climate setting and meteorological data}

In analysis we used monthly and daily climate data obtained from the KNMI climate explorer (www.climexp.knmi.nl) (Trouet \& Oldenbourgh, 2013) and from the USA National Snow and Ice Data Center (NSIDC) (Table 2). Databases we used include: the Global Historical Climatology Network (GHCN)-Daily v.2 database (Menne et al., 2012), Climate Research Unit (CRU) TS 4.00 (Harris et al., 2014) and Central Asia temperature and precipitation data, 1879-2003 (Williams \& Konovalov,
2008). We used data from the Almaty weather station (WMO number 36870) because it is the nearest station (straight-line distance to the sampling site is $17 \mathrm{~km}$ ). In order to exclude the influence of different length of climate datasets on correlation results, we limited the length of all climate datasets and chronologies to the length of the minimal available period, from 1926 to 1982 . Different climatic parameters were taken into consideration, including: precipitation, maximum, minimum and average temperature. Drought was investigated using the Standardized Precipitation Evapotranspiration Index (SPEI). The SPEI is basically a difference between potential evapotranspiration (PET) and precipitation, so for instance 12-month SPEI is a difference between PET and precipitation accumulated over the 11 months before to the current month. We did analysis with all SPEI datasets available on the KNMI climate explorer, trying to find the best correlations.

The climate in the region in general is characterized by strong seasonality in temperature with maximum in July and August, and bimodal precipitation regime, with two peaks, one in April-May and second in October-November (Fig. 2). The mean annual air temperatures (MAAT) is around $9.1^{\circ} \mathrm{C}$ and mean annual precipitation totals are about $620 \mathrm{~mm}$, with fluctuations ranging from 570 to $710 \mathrm{~mm}$ during the period from 1894 to 2011. Also we should mention that the bimodal precipitation regime recorded in Almaty is not so pronounced at higher elevations where we have just one peak from April to August instead of two.

Table 2. Climate data

\begin{tabular}{lcclc}
\hline Climate data & $\begin{array}{c}\text { Observation } \\
\text { period }\end{array}$ & Coordinates & \multicolumn{1}{c}{ Climatic parameters } \\
\hline $\begin{array}{l}\text { Almaty station } \\
\text { (monthly data) }\end{array}$ & $1926-1982$ & $43.23^{\circ} \mathrm{N}, 76.93^{\circ} \mathrm{E}$, & $\begin{array}{l}\text { Precipitation; Average, Maximum and } \\
\text { Minimum temperature }\end{array}$ \\
$\begin{array}{l}\text { Almaty station } \\
\text { (daily data) }\end{array}$ & $1926-1982$ & $43.23^{\circ} \mathrm{N}, 76.93^{\circ} \mathrm{E}$, & $\begin{array}{l}\text { Precipitation; Average, Maximum and } \\
\text { Minimum temperature }\end{array}$ \\
$\begin{array}{l}\text { Gridded data } \\
\text { CRU TS 4.00 }\end{array}$ & $1926-1982$ & $43.05^{\circ} \mathrm{N}, 76.45^{\circ} \mathrm{E}$, & $\begin{array}{l}\text { Precipitation; Average, Maximum and } \\
\text { Kinimum temperature and SPEI }\end{array}$ \\
\hline
\end{tabular}
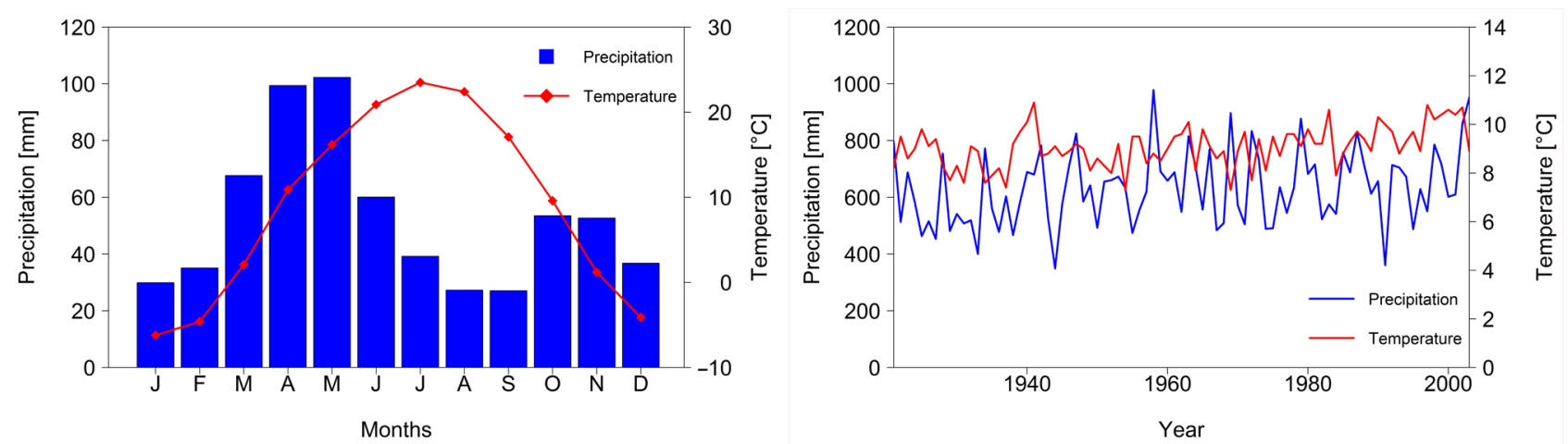

Fig. 2. Temperature and precipitation graphs for the period 1921-2003, left - monthly average, right - annual precipitation totals and MAAT, based on the Almaty weather station 
The temperature has an increasing trend and the rate became faster after 1982, whereas precipitation had a decreasing trend at the beginning of the last century, after that, the trend leveled and became a nearly flat line from 1958 to 2010 (Cherednichenko et al., 2015). Monthly data correlations, including spatial correlations, were analyzed in the KNMI climate explorer, and daily data using the (CLIMTREG V4) program (Beck et al., 2013). The CLIMTRE $\bar{G}$ calculates correlations starting in July of the last year running to the end of October of the current year. The correlation starts with a 21 days window shifting every time by one day. After this the program starts calculation again but now with 22 days window. The process continues until reaching 121 days. In the end it presents the best correlation results which were found. In order to check the temporal stability of the climatic signal, the running correlation with 30 years window and minimum number of years with data $=$ 1 was applied. Spatial correlation analysis shows the geographic representation of our chronology. It was performed for the territory $\left(35^{\circ}-55^{\circ} \mathrm{N}, 45^{\circ} \mathrm{E}-95^{\circ} \mathrm{E}\right)$, which covers the whole Central Asia, northwestern China, western Mongolia and adjacent territories of Russia. Climatic parameters investigated on spatial correlations include precipitation, average, minimum and maximum temperature and the SPEI. We checked correlations for both previous and current years, because growth in the current year can be affected by the precipitation and temperature conditions of previous year (Schweingruber, 1996).

\section{Results}

\section{Chronologies and sensitivity}

Three residual chronologies of EW, LW and TRW were built for each group of trees. In total, eight chronologies were taken into account for correlation analysis. Due to insufficient values of EPS and Rbar, LW chronology of young trees was excluded from the analysis (Fig. 3). All other chronologies demonstrate good quality and applicability for climate correlation analysis, for the period 1926-1982. Chronology statistics obtained from the ARSTAN program are presented in Table 3. Data analysis revealed the differences in mean sensitivity among all datasets. In general the LW shows higher sensitivity. EW and TRW have more or less equal values that vary from 0.19 to 0.27 . The intercorrelation between individual measurement series was lower for LW and higher for EW and TRW. Rather high values of the variance in the first eigenvector indicate similarity of signals reflected by each group of trees. In all cases, the highest value of mean sensitivity (MS) were found for young trees whereas old trees show the lowest values, which is interesting because contradicts the Borscheva's findings (Table 3 ).

\section{Results of correlation analysis}

Correlations between various tree-ring parameters and all age groups with daily climate data revealed
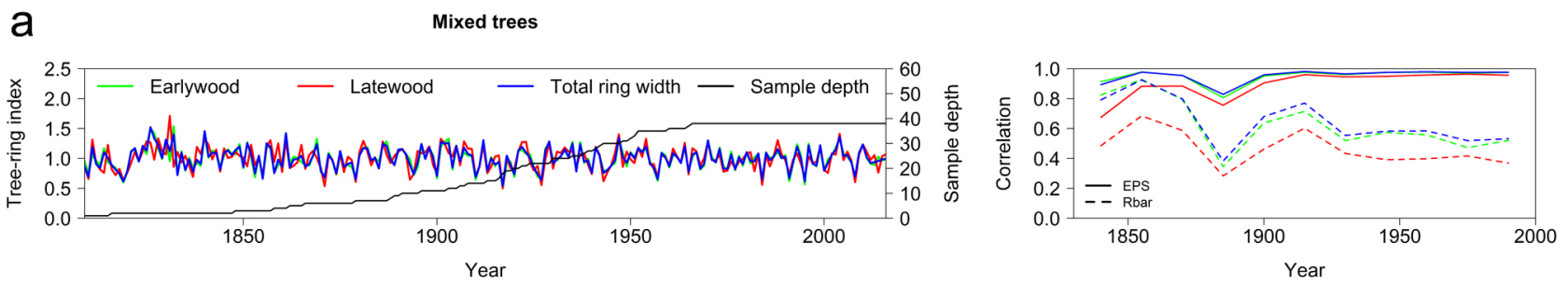

\section{b}

Old trees
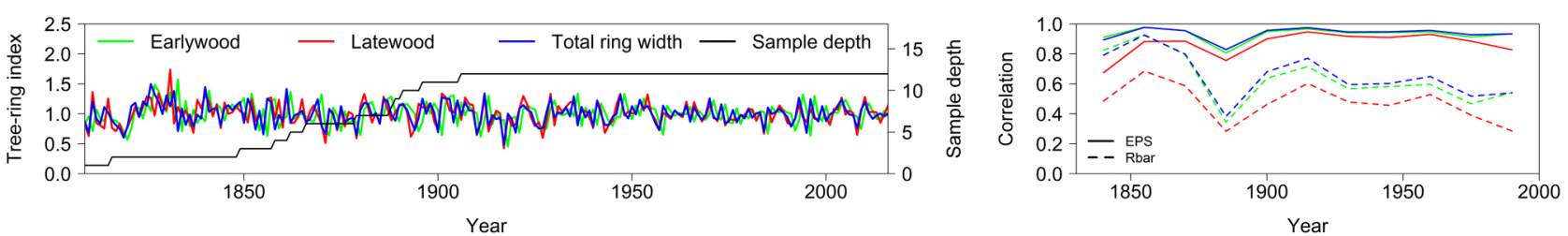

\section{C}

Young trees
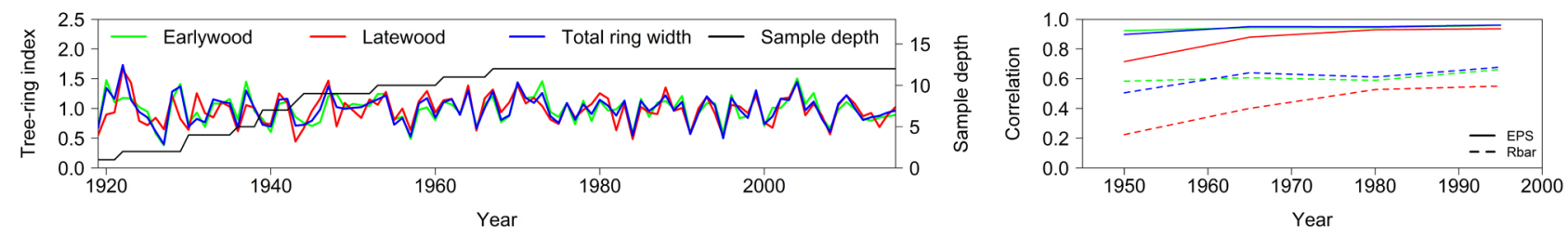

Fig. 3. Tree-ring residual chronologies and sample depth of all (a), old (b) and young (c) trees. EPS and Rbar statistics calculated over a 30-year period lagged by 15 years (right). Green line - EW, redline - LW and blue line - TRW 
Table 3. Statistics for the residual chronologies

\begin{tabular}{|c|c|c|c|c|c|c|c|c|}
\hline Chronology & EW all & EW old & EW young & LW all & LW old & TRW all & TRW old & TRW young \\
\hline Chronology time span & $1808-2016$ & $1808-2016$ & 1919-2016 & $1808-2016$ & $1808-2016$ & $1808-2016$ & $1808-2016$ & $1919-2016$ \\
\hline Common interval & 1967-2016 & 1906-2016 & 1967-2016 & 1967-2016 & 1906-2016 & 1967-2016 & 1906-2016 & 1967-2016 \\
\hline Number of trees and radii & $\begin{array}{l}21 \text { trees } \\
38 \text { radii }\end{array}$ & $\begin{array}{l}7 \text { trees } \\
12 \text { radii }\end{array}$ & $\begin{array}{l}7 \text { trees } \\
12 \text { radii }\end{array}$ & $\begin{array}{l}21 \text { trees } \\
38 \text { radii }\end{array}$ & $\begin{array}{l}7 \text { trees } \\
12 \text { radii }\end{array}$ & $\begin{array}{l}21 \text { trees } \\
38 \text { radii }\end{array}$ & $\begin{array}{l}7 \text { trees } \\
12 \text { radii }\end{array}$ & $\begin{array}{l}7 \text { trees } \\
12 \text { radii }\end{array}$ \\
\hline MS $^{\mathrm{a}}$ & 0.21 & 0.20 & 0.27 & 0.22 & 0.21 & 0.21 & 0.19 & 0.27 \\
\hline $\mathrm{SD}^{\mathrm{b}}$ & 0.18 & 0.18 & 0.23 & 0.19 & 0.19 & 0.18 & 0.17 & 0.23 \\
\hline $\mathrm{SNR}^{\mathrm{c}}$ & 29.10 & 9.49 & 13.16 & 16.66 & 6.81 & 32.00 & 11.24 & 14.50 \\
\hline $1 \mathrm{EV}^{\mathrm{d}}(\%)$ & 58.09 & 59.00 & 67.39 & 42.77 & 48.59 & 60.74 & 63.38 & 70.78 \\
\hline $\begin{array}{l}\text { Mean correlation between } \\
\text { all series }\end{array}$ & 0.53 & 0.53 & 0.61 & 0.36 & 0.42 & 0.55 & 0.57 & 0.64 \\
\hline EPS $^{\mathrm{e}}$ & 0.97 & 0.90 & 0.93 & 0.94 & 0.87 & 0.97 & 0.92 & 0.94 \\
\hline
\end{tabular}

${ }^{\mathrm{a}} \mathrm{MS}$ Mean sensitivity,

${ }^{\mathrm{b}} S D$ Standard deviation,

'SNR Signal-to-noise ratio,

${ }^{\mathrm{d}} 1 E V$ Variance in first eigenvector

eEPS Expressed population signal,

Correlations are statistically significant $(\mathrm{p}<0.05)$.

Table 4. Strongest correlations between different climate datasets and chronologies of different age groups of trees. Precipitation correlated with EW, temperature with LW and the SPEI 12 with TRW (please note correlations increasing from left to right)

\begin{tabular}{lcccc}
\hline $\begin{array}{c}\text { Climatic } \\
\text { parameter }\end{array}$ & $\begin{array}{c}\text { CRU TS 4.00 } \\
\text { (only mixed trees) }\end{array}$ & $\begin{array}{c}\text { CRU TS 4.00 } \\
\text { (all groups) }\end{array}$ & $\begin{array}{c}\text { Monthly station data } \\
\text { (all groups) }\end{array}$ & $\begin{array}{c}\text { Daily station data } \\
\text { (all groups) }\end{array}$ \\
\hline Precipitation & $0.35^{* * *}$ & $0.37^{* *}$ & $0.43^{* * *}$ & $0.64^{* *}$ \\
& previous July & July & October & $\begin{array}{c}\text { previous July } 6^{\text {th }}-\text { November } 3^{\text {rd }} \\
\text { Average }\end{array}$ \\
temperature & $-0.48^{* * *}$ & $-0.48^{* * *}$ & $-0.52^{* * *}$ & $-0.67^{* * *}$ \\
Minimum & July & July & July & June $11^{\text {th }}-$ August $4^{\text {th }}$ \\
temperature & $-0.42^{* * *}$ & $-0.42^{* * *}$ & $-0.50^{* * *}$ & $-0.64^{* * *}$ \\
Maximum & July & July & July & June $11^{\text {th }}-$ August $4^{\text {th }}$ \\
temperature & $-0.50^{* * *}$ & $-0.50^{* * *}$ & $-0.52^{* * *}$ & $-0.66^{* * *}$ \\
SPEI 12 & July & July & July & June $25^{\text {th }- \text { July } 17^{\text {th }}}$ \\
& $0.53^{* * *}$ & $0.61^{*}$ & - & - \\
\hline
\end{tabular}

*young trees, ${ }^{* *}$ old trees, ${ }^{* * *}$ mixed trees, correlations are statistically significant $(\mathrm{p}<0.05)$.

Table 5. Correlation results in the CLIMTREG, between daily climate data and different age groups and tree-ring parameters

\begin{tabular}{|c|c|c|c|c|c|c|c|}
\hline \multirow{2}{*}{$\begin{array}{l}\text { Tree-ring } \\
\text { parameter }\end{array}$} & \multirow{2}{*}{$\begin{array}{l}\text { Climatic } \\
\text { parameter }\end{array}$} & \multicolumn{2}{|c|}{ Young trees } & \multicolumn{2}{|c|}{ Old trees } & \multicolumn{2}{|l|}{ Mixed trees } \\
\hline & & Period & $\begin{array}{l}\text { Number } \\
\text { of days }\end{array}$ & Period & $\begin{array}{l}\text { Number } \\
\text { of days }\end{array}$ & Period & $\begin{array}{c}\text { Number } \\
\text { of days }\end{array}$ \\
\hline EW & Precipitation & $\begin{array}{l}\text { Previous July } 6^{\text {th }}- \\
\text { November } 2^{\text {nd }}\end{array}$ & 119 & $\begin{array}{l}\text { Previous July } 6^{\text {th }}- \\
\text { November } 3^{\text {rd }}\end{array}$ & 120 & $\begin{array}{c}\text { Previous July } 6^{\text {th }}-\text { No- } \\
\text { vember } 3^{\text {rd }}\end{array}$ & 120 \\
\hline \multirow[t]{3}{*}{ LW } & $\begin{array}{l}\text { Average } \\
\text { temperature }\end{array}$ & - & - & June $23^{\text {rd }}$-July $16^{\text {th }}$ & 23 & June $11^{\text {th }}$-August $4^{\text {th }}$ & 54 \\
\hline & $\begin{array}{l}\text { Minimum } \\
\text { temperature }\end{array}$ & - & - & June $23^{\text {rd }}-$ July $20^{\text {th }}$ & 27 & June $11^{\text {th }}$-August $4^{\text {th }}$ & 54 \\
\hline & $\begin{array}{l}\text { Maximum } \\
\text { temperature }\end{array}$ & - & - & June $23^{\text {rd }-J u l y ~} 16^{\text {th }}$ & 23 & June $25^{\text {th }}$ July $17^{\text {th }}$ & 22 \\
\hline
\end{tabular}

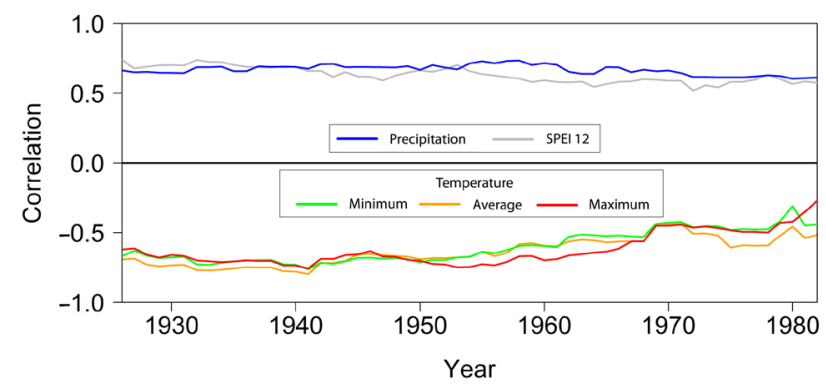

Fig. 4. The running correlation analysis (window size $=$ 30 years, minimum number of years with data $=1$ ). Correlation values for precipitation and SPEI 12 signals are significant during the entire observation period $(p<0.05)$ and temperature signals are significant only until 1979 
stronger relationships than with monthly CRU data or monthly station data (Table 4). The analysis revealed that the TRW better correlates with the SPEI 12; EW yielded the strongest correlation with precipitation and LW with temperature (Table 5). Results of the running correlation analysis showed the temporal stability of precipitation and SPEI 12 signals. The correlation values vary from $0.6(\mathrm{p}<0.05)$ to $0.74(\mathrm{p}<0.001)$ and from $0.52(\mathrm{p}<0.01)$ to 0.74 $(\mathrm{p}<0.001)$, for precipitation and SPEI respectively. In contrast, the temperature signal showed gradual decreasing of correlation from 1926 to 1982 becoming insignificant after 1979 (Fig. 4). The correlation values vary from $-0.76(p<0.001)$ to $-0.31(p>0.2)$ for minimum temperature, from $-0.8(\mathrm{p}<0.001)$ to $-0.44(\mathrm{p}<0.05)$ for average temperature and from $-0.76(\mathrm{p}<0.001)$ to $-0.27(\mathrm{p}>0.3)$ for maximum temperature.

\section{Spatial correlation}

The spatial correlation with different climatic parameters revealed that the best correlations are mainly associated with the territory of Kazakhstan, but some correlations are also found in the adjacent territories of Kyrgyzstan and China (Fig. 5). Correlations with temperatures show gradual changes whereas precipitation and drought have more heterogeneous patterns. The EW of old trees shows best correlation with precipitation, and TRW of young trees shows stronger and more precise correlation with the SPEI drought index. Spatial field correlations between temperature and old trees cover a smaller area compared to mixed trees, which cover a bigger territory stretching up to central Kazakhstan. Also it was noted that correlations with mixed dataset provides better results compared to old and young trees separately (Fig. 6).

\section{Discussion}

The weak statistical results of the LW chronology of young trees can be due to so called "Divergence Problem" and associated with reduction of sensitivity and changes in the structure of temperature signal in radial tree growth since the middle $20^{\text {th }}$ century (D'Arrigo et al., 2008). This assumption is also supported by our running correlation analysis, which showed the decreasing of the temperature signal. Higher values of MS and the variance in the first eigenvector for young trees indicate higher dependence on environmental conditions compared to old trees. These results are also in agreement with the results reported in $\mathrm{Wu}$ et al. (2013). According to Borscheva (1983) differences in sensitivity between trees of different age are connected to critical periods of ontogenesis, middle age trees are characterized by intensive seeding which make them more sensitive to environmental changes. This could be the reason why our young trees showed higher MS compared to old trees. The ratio between latewood and earlywood also has direct connections to sensitivity, the more the latewood content the higher the sensitivity (Borscheva, 1986).

Young trees show higher sensitivity to drought conditions compared to old trees since this is a limiting factor, which determines the vegetation period for them. Old trees in contrast, have ample sunlight, fully developed root systems that assists in drought tolerance, but they are more sensitive to the availability of water resources (Kozhevnikova, 1981). The common period when drought affects both age groups is current June-July. Correlations with temperatures in current July, especially with maximum temperature is also in agreement with Borscheva's results (1983) which showed that, in July LW formation starts and we see that temperature has the primal effect on this process. Negative correlations with temperature in July are also in agreement with results published by Magnuszewski et al. (2015). It can be also considered as a manifestation of drought stress, because low precipitation and high temperature can affect the production of sugars (LaMarche, 1974). The LW formation of old and young trees, which is driven by temperature characteristics, starts and ends in different time periods. Hence, if we do seasonal averaging, we should use mixed datasets, since it can cover the whole period of LW formation and better reflects temperature changes. Such age-dependent differences in climatic sensitivity were reported for various tree species (Vieira et al., 2009; Yu et al., 2008; Wang et al., 2009; Rozas et al., 2009). There are many explanations why this difference exists, for example variations in the period of xylem growth (Rossi et al., 2008), lower photosynthetic rates in older trees (Bond, 2000), or increasing of hydraulic resistance (Carrer \& Urbinati, 2004).

Another interesting fact was a shifting of strongest correlations values for precipitation. The CRU data demonstrate highest values between EW and precipitation in previous July, whereas station data showed strongest correlation with precipitation in previous October. This shifting probably can be explained by differences in altitude between station and sampling site and also by some orographic features. In general the highest correlations were found in the period from previous July to previous November. This shows that the previous year affects the content of EW, and wet conditions are beneficial for trees, because this reduces evapotranspiration and helps to save moisture for the next vegetation period which is also in agreement of results reported by Chen et al. (2017). 


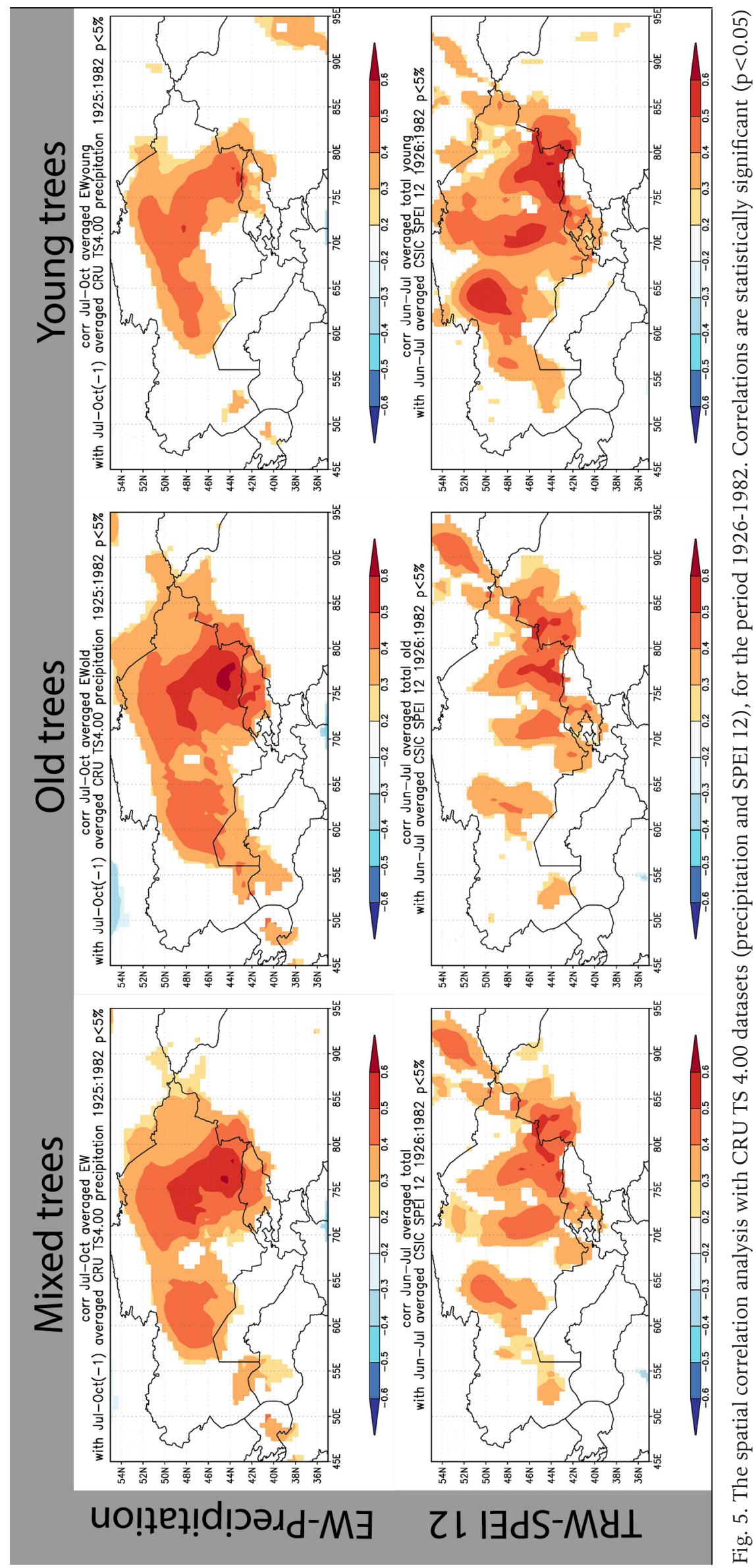




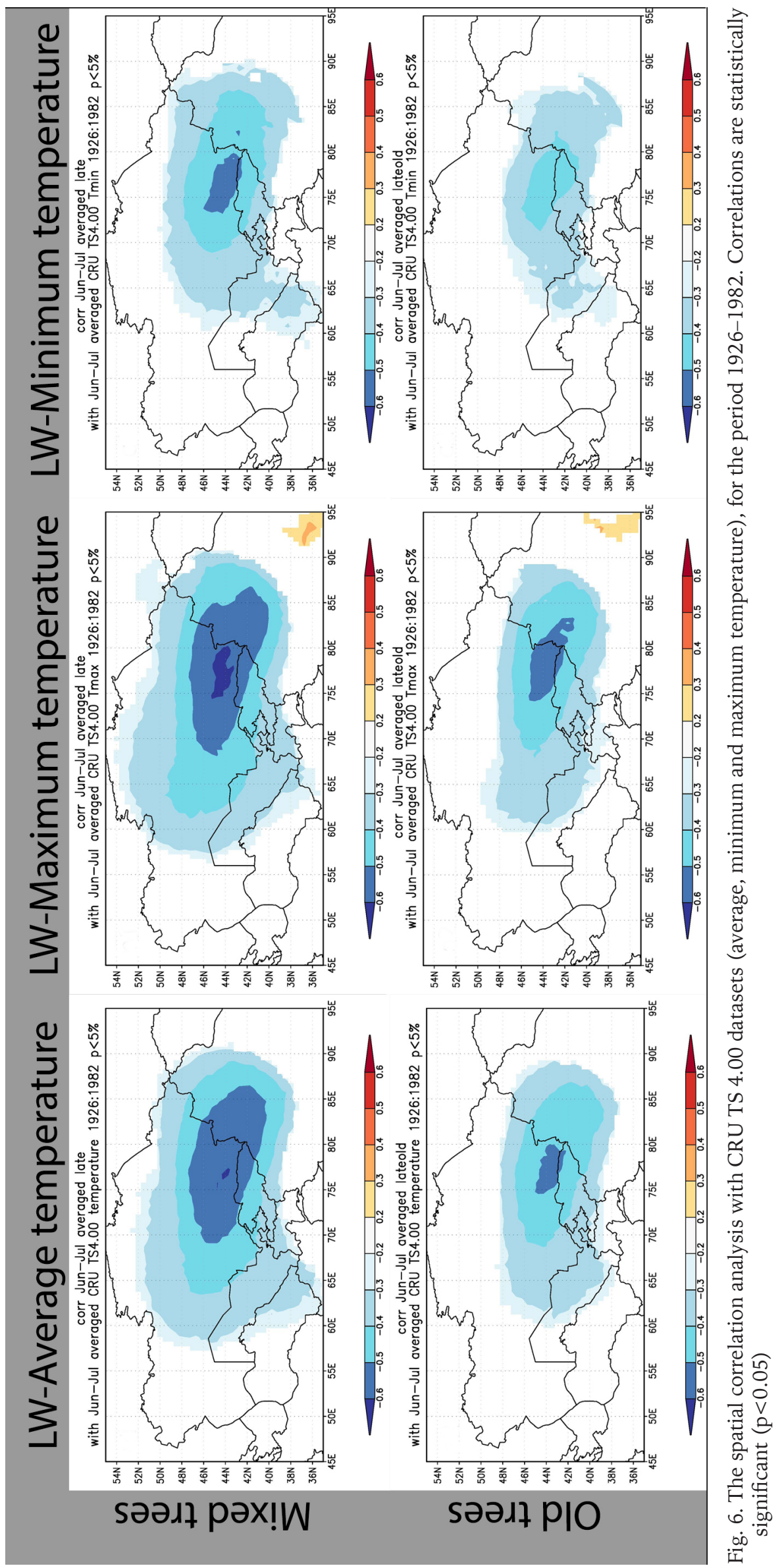


The spatial correlations demonstrated a significant influence of orography and difference in precipitation regime. The Terskey Alatau and the Kungey Alatau located further to the East and the South from our sampling site are closed for entrance of northern and northwestern air masses (Aizen et al., 1997; Bolch, 2007). This probably explains a difference in reaction of Schrenk spruce in northern and central Tian Shan, when MS grows with altitude in the Trans-Ili Alatau (Roldugin, 1970; Kolov et al., 2003), but decreases in the central Tian Shan in China (Wang et al., 2005). Spatial correlations again demonstrated that each age group of trees captures specific signals and combined into a mixed dataset they provide better results. However a considerable amount of uncertainty still remains regarding what are the physiological reasons of differences in climatic sensitivity between old and young trees of Schrenk spruce in northern Tian Shan. Therefore further efforts are required in order to clarify this question.

Our results support our hypothesis. In all tests with daily climate data EW and LW provide strongest correlations with precipitation and temperature respectively. We see the obvious potential of using various tree-ring parameters of Schrenk spruce, for example in future dendroclimatic studies, since this gives a possibility to reconstruct several climatic parameters using the same trees each time.

\section{Conclusion}

We investigated how different combinations of climatic and tree rings datasets affect correlation results based on data collected in the southeastern part of Kazakhstan. For the first time, correlations between EW, LW and daily climate data for Schrenk spruce in the Trans-Ili Alatau (northern Tian Shan) were investigated.

Results indicate EW correlates most strongly with precipitation, LW responds best to temperature, and total ring width is mainly drought sensitive. Analysis using daily climate data demonstrated its perspective, providing better correlation values and more precise time intervals. Old trees yield better correlation results with precipitation. Mixed trees demonstrate best results with temperature and drought records. A shifting of strongest correlations in time was found, between EW and precipitation, when we use CRU data and station data. All this indicates the importance, of taking into consideration, which climate datasets, tree-ring parameters and age group we use in dendroclimatic research, because these have direct influence on correlation results.

This study is a small step towards understanding the relationships between climate conditions and spruce forest growth in Southeast Kazakhstan.
In order to increase reliability of the analysis more samples need to be collected, therefore this study presents just a preliminary results. Moreover, based upon our findings it is possible that trees in the middle and upper forest belts may also show varying climate-growth relationships depending upon age class. Implementation of new methods like stable isotope and wood anatomy analysis can provide additional climatic information and complement ring width analyses.

\section{Acknowledgements}

This study has been supported through funding from the German Academic Exchange Service (DAAD) scholarship program: Research Grants Doctoral Programs in Germany, 2015/16. Authors would like to acknowledge Alexander Janus, Sergey Varchenko and Sergey Biketov for assistance in the lab and in the field work. We thank Sam Cooper and Kamilla Majidova for editing the English language. We are also grateful to Ingo Heinrich and Daniel Balanzategui for their support and fruitful discussions. The authors also thank the editor and the reviewers for constructive comments to improve the manuscript.

\section{References}

Aizen VB, Aizen EM, Melack JM \& Dozier J (1997) Climatic and hydrologic changes in the Tien Shan, central Asia. Journal of Climate 10: 1393-1404. doi:10.1175/1520-0442(1997)010<1393:CAHCIT>2.0.CO;2.

Beck W, Sanders TG \& Pofahl U (2013) CLIMTREG: detecting temporal changes in climate-growth reactions - a computer program using intra-annual daily and yearly moving time intervals of variable width. Dendrochronologia 31: 232-241. doi:10.1016/j.dendro.2013.02.003.

Bolch T (2007) Climate change and glacier retreat in northern Tien Shan (Kazakhstan/Kyrgyzstan) using remote sensing data. Global and Planetary Change 56: 1-12. doi:10.1016/j.gloplacha.2006.07.009.

Bond BJ (2000) Age-related changes in photosynthesis of woody plants. Trends in Plant Science 5: 349-353. doi:10.1016/S1360-1385(00)01691-5.

Borscheva NM (1981a) Vlijanie klimaticheskih faktorov na radial'nyi prirost drevesiny Eli Shrenka v Zailijskom Alatau: Bioekologicheskie issledovanija v elovyh lesah Tyan'-Shanya (ed. by R Krinickaja) Ilim, Frunze, pp. 159-167.

Borscheva NM (1981b) Vlijanie biologicheskih osobennostej na formirovanie godičnyh kolec Eli Shrenka v Kungej Alatau: Bioèkologicheskie issle- 
dovanija v elovyh lesah Tyan'-Shanya (ed. by R Krinickaja) Ilim, Frunze, pp. 154-159.

Borscheva NM (1981c) Dinamika godichnogo prirosta Eli Shrenka na severnom sklone hrebta Kunglej Alatau: Dendroklimatologicheskie shkaly Sovetskogo Sojuza (chast' II) (ed. by T Bitvinskas) Institut Botaniki AN Lit.SSR, Kaunas, pp. 24-27.

Borscheva NM (1981d) Dendrohronologicheskie shkaly Eli Shrenka v gorah Zailijskogo Alatau (Severnyj Tyan'-Shan'): Dendroklimatologicheskie shkaly Sovetskogo Sojuza (chast' II) (ed. by T Bitvinskas) Institut Botaniki AN Lit.SSR, Kaunas, pp. 17-23.

Borscheva NM (1983) Dendroklimaticheskij analiz radial'nogo prirosta Eli Shrenka v gorah severnogo Tyan'-Shanya. Avtoreferat diss. na soiskanie uchenoj stepeni kand. geograficheskih nauk, Sverdlovsk.

Borscheva NM (1986) Vlijanie biologicheskih I klimaticheskih faktorov na radial'nyj prirost Eli Shrenka: Dendrohronologija i dendroklimatologija (ed. by LA Kairukstis, GI Galazy \& SG Shiyatov) Nauka, Novosibirsk, pp. 71-76.

Bunn AG (2008) A dendrochronology program library in R (dplR). Dendrochronologia 26: 115124.

Carrer M \& Urbinati C (2004) Age-dependent tree-ring growth responses to climate in Larix decidua and Pinus cembra. Ecology 85: 730-740. doi:10.1890/02-0478.

Chen F, Mambetov B, Maisupova B \& Kelgenbayev N (2017) Drought variations in Almaty (Kazakhstan) since AD 1785 based on spruce tree rings. Stochastic Environmental Research and Risk Assessment 31: 2097-2105. doi:10.1007/s00477016-1290-y.

Cherednichenko A, Cherednichenko A, Vilesov EN \& Cherednichenko VS (2015) Climate change in the City of Àlmaty during the past 120 years. Quaternary International 358: 101-105.

Cook ER \& Holmes RL (1986) User's manual for program ARSTAN: Tree-ring chronologies of western North America (ed. by RL Holmes, RK Adams \& HC Fritts) California, eastern Oregon and northern Great Basin. University of Arizona, Tucson, USA, pp. 60-86.

Cook ER \& Peters K (1997) Calculating unbiased tree-ring indices for the study of climatic and environmental change. The Holocene 7: 361-370. doi:10.1177/095968369700700314.

D'Arrigo R, Wilson R, Liepert B \& Cherubini P (2008) On the 'Divergence Problem' in Northern Forests: A review of the tree-ring evidence and possible causes. Global and Planetary Change 60: 289-305. doi:10.1016/j.gloplacha.2007.03.004.
Gan PA (1970) Ecologicheskie osnovy introdukcii i lesorazvedeniya $\mathrm{v}$ pojase elovyh lesov Tyan'-Shanya. Ilim, Frunze.

Harris I, Jones PD, Osborn TJ \& Lister DH (2014) Updated high-resolution grids of monthly climatic observations - the CRU TS3.10 Dataset. International Journal of Climatology 34: 623-642. doi:10.1002/joc.3711.

Holmes RL (1983) Computer-assisted quality control in tree-ring dating and measurement. TreeRing Bulletin 43: 69-78.

Kolov OV, Dzhumadilova CK, Hudaibergenov AD \& Stuparik R (2003) Izmenenie klimata i ego vlijanie na lesnye ekosistemy Kyrgyzskoy Respubliki. Vestnik KRSU 6. http://www.krsu.edu.kg/ vestnik/2003/v6/a09.html.

Kozhevnikova ND (1981) Morfologicheskie osobennosti Eli Shrenka $\mathrm{v}$ ontogeneticheskom ryadu vozrastnyh sostojaniy: Bioekologicheskie issledovanija v elovyh lesah Tyan'-Shanya (ed. by R Krinickaja) Ilim, Frunze, pp. 68-93.

LaMarche VC (1974) Paleoclimatic inferences from long tree-ring records. Science 183: 1043-1048.

Magnuszewski M, Bijak S, Orozumbekow A, Howe B, Musuraliev K, Zasada M, Bronisz K \& Bronisz A (2015) Different growth patterns of Picea schrenkiana subsp. tianshanica (Rupr.) Bykov and Juglans regia L. coexisting under the same ecological conditions in the Sary-Chelek Biosphere Reserve in Kyrgyzstan. Dendrobiology 73: 11-20. doi:10.12657/denbio.073.002.

Meko DM, Touchan R \& Anchukaitis KJ (2011) Seascorr: a MATLAB program for identifying the seasonal climate signal in an annual tree-ring time series. Computers \& Geosciences 37: 1234-1241. doi:10.1016/j.cageo.2011.01.013.

Menne MJ, Durre I, Vose RS, Gleason BE \& Houston TG (2012) An overview of the global historical climatology network - daily database. Journal of Atmospheric and Ocean Technology 29: 897-910. doi:10.1175/JTECH-D-11-00103.1.

Panyushkina IP, Chang C, Clemens AW \& Bykov N (2010) First tree-ring chronology from Andronovo archaeological timbers of Bronze Age in Central Asia. Dendrochronologia 28: 13-21. doi:10.1016/j.dendro.2008.10.001.

Panyushkina IP, Meko DM, Macklin MG, Toonen WHJ, Mukhamadiev NS, Konovalov VG, Ashikbaev NZ \& Sagitov AO (2018) Runoff variations in Lake Balkhash Basin, Central Asia, 1779-2015, inferred from tree rings. Climate Dynamics: 1-17. doi:10.1007/s00382-018-4072-z.

Passmore DG, Harrison S, Winchester V, Rae A, Severskiy I \& Pimankina NV (2004) Recent historic debris flows and valley floor development in the northern Zailiiskiy Alatau, Tien Shan Mountains, Kazakhstan: Water resources in the basin of the 
Ili River (Republic of Kazakhstan) (ed. by $\mathrm{H}$ Schröder \& I Severskiy) Mensch \& Buch Verlag, Berlin, pp. 288-310.

Roldugin II (1970) El' Shrenka v Severo-Vostochnom Tyan'-Shane. Avtoreferat diss. na soiskanie uchenoj stepeni kand. s-h. nauk, Alma-ata.

Rossi S, Deslauriers A, Anfodillo T \& Carrer M (2008) Age-dependent xylogenesis in timberline conifers. New Phytologist 177: 199-208. doi:10.1111/j.1469-8137.2007.02235.x.

Rozas V, DeSoto L \& Olano JM (2009) Sex-specific, age-dependent sensitivity of tree-ring growth to climate in the dioecious tree Juniperus thurifera. New Phytologist 182: 687-697.

Schweingruber FH (1996) Tree rings and environment: dendroecology. Paul Haupt AG, Bern.

Speer JH (2010) Fundamentals of tree-ring research. University of Arizona Press.

Tachikawa T, Hato M, Kaku M \& Iwasaki A (2011) Characteristics of ASTER GDEM version 2. Geoscience and remote sensing symposium (IGARSS), 2011 IEEE international.

Trouet V \& Van Oldenborgh GJ (2013) KNMI Climate Explorer: a web-based research tool for high-resolution paleoclimatology. Tree-Ring Research 69: 3-13. doi:10.3959/1536-1098-69.1.3.

Vicente-Serrano SM, Beguería S \& López-Moreno JI (2010) A multiscalar drought index sensitive to global warming: the standardized precipitation evapotranspiration index. Journal of Climate 23: 1696-1718. doi:10.1175/2009JCLI2909.1.

Vieira J, Campelo F \& Nabas C (2009) Age-dependent responses of tree-ring growth and intra-annual density fluctuations of Pinus pinaster to Mediter- ranean climate. Trees 23: 257-265. doi:10.1007/ s00468-008-0273-0.

Williams MW \& Konovalov VG (2008) Central Asia temperature and precipitation data, 1879-2003. USA National Snow and Ice Data Center, Boulder, Colorado.

Wang T, Ren H \& Ma K (2005) Climatic signals in tree ring of Picea schrenkiana along an altitudinal gradient in the central Tianshan Mountains, northwestern China. Trees 19: 736-742. doi:10.1007/ s00468-005-0003-9.

Wang X, Zhang Y \& McRae DJ (2009) Spatial and age-dependent tree-ring growth responses of Larix gmelinii to climate in northeastern China. Trees 23: 875-885. doi:10.1007/s00468-009-0329-9.

Wigley TML, Briffa KR \& Jones PD (1984) On the average value of correlated time series, with applications in dendroclimatology and hydrometeorology. Journal of Applied Meteorology 23: 201-213.

Wu G, Xu G, Chen T, Liu X, Zhang Y, An W, Wang W, Fang ZA \& Yu S (2013) Age-dependent tree-ring growth responses of Schrenk spruce (Picea schrenkiana) to climate - A case study in the Tianshan Mountain, China. Dendrochronologia 31: 318326. doi:10.1016/j.dendro.2013.01.001.

Yu G, Liu Y, Wang X \& Ma K (2008) Age-dependent tree-ring growth responses to climate in Qilian juniper (Sabina przewalskii Kom.). Trees 22: 197204. doi:10.1007/s00468-007-0170-y.

Zhang R, Shang H, Yu S, He Q, Yuan Y, Bolatov K \& Mambetov BT (2017) Tree-ring based precipitation reconstruction in southern Kazakhstan, reveals drought variability since AD 1770 . International Journal of Climatology 37: 741-750. 